\title{
ASSOCIATION BETWEEN MATERNAL WEIGHT AND A NEWBORN WEIGHT IN SURAKARTA, CENTRAL JAVA
}

\author{
Rahmi Syuadzah", Hari Wahyu Nugroho', Safitri Tia Tampy" \\ 1) Pediatric Research Center, Department of Child Health, \\ Dr. Moewardi Hospital, Surakarta \\ 2) Faculty of Medicine, Universitas Sebelas Maret, Surakarta
}

\begin{abstract}
Background: In Indonesia, nutrition is still the 5 biggest problem for mothers and children. Nutrition in the mother during pregnancy will affect the nutrition the infant gets while in the womb. Nutrition in children is very important in the first 1000 days of life because it will affect the growth and development of the infant. One way to assess the nutritional adequacy of new born is by measuring the infant's weight at birth. This study aimed to determine the relationship between maternal weight and birth weight.

Subjects and Method: This was a cross sectional study conducted at Pajang Community Health Center, Surakarta, Central Java. The study subjects were all mothers and infants whose birth weight were measured during February to March 2020. The dependent variable in this study was maternal weight. The independent variable was birth weight. The data were taken from the medical records of the Pajang Community Health Center. The data were analyzed using logistic regression test

Results: Maternal weight below the normal weight had tendency to produce babies with less weight than pregnant women with normal maternal weight $(\mathrm{OR}=55.00 ; \mathrm{p}<0.001)$, and it was statistically significant.

Conclusion: There is a significant relationship between maternal weight of pregnant women and birth weight
\end{abstract}

Keywords: maternal weight, birth weight

\section{Correspondence:}

Rahmi Syuadzah. Pediatric Research Center (PRC), Department of Child Health, Dr. Moewardi Hospital, Surakarta. Jl. Colonel Sutarto, Jebres, Kec. Jebres, Surakarta City, Central Java 57126. Email: Rahmi_syuadzah@yahoo.com. Mobile: 082144806405 